Cortès, M., Llasat, M.C., Gilabert, J. et al. Nat Hazards (2017) 93(Suppl 1): 39.

https://doi.org/10.1007/s11069-017-3014-0

\title{
Towards a better understanding of the evolution of the flood risk in Mediterranean urban areas: the case of Barcelona
}

\author{
Maria CORTÈS ${ }^{(1)}$, Maria Carmen LLASAT ${ }^{(1)}$, Joan GILABERT ${ }^{(1,2)}$, Montserrat LLASAT-BOTIJA ${ }^{(1)}$, Marco \\ TURCO $^{(1)}$, Raül MARCOS ${ }^{(3)}$, Juan Pedro MARTíN VIDE ${ }^{(4)}$, Lluís FALCÓN ${ }^{(5)}$ \\ ${ }^{1}$ GAMA, Department of Applied Physics, University of Barcelona, Spain, mcortes@meteo.ub.edu \\ ${ }^{2}$ Cartographic and Geological Institute of Catalonia \\ ${ }^{3}$ Barcelona Supercomputing Center- Centro Nacional de Supercomputación, Barcelona \\ ${ }^{4}$ Dept. of Civil and Environmental Engineering, UPC, Barcelona Tech \\ ${ }^{5}$ Urban architect, FALCON architecture and urbanism
}

\begin{abstract}
This contribution explores the evolution of the flood risk in the Metropolitan Area of Barcelona (MAB; Northeast Spain) from 1981 to 2015, and how it has been affected by changes in land use, population and precipitation. To complete this study, we analysed PRESSGAMA and INUNGAMA databases to look for all the information related to the floods and flash floods that have affected the chosen region. The "Consorcio de Compensación de Seguros", a state insurance company for extraordinary risks, provided data on economic damage. The extreme precipitation trend was analysed by the Fabra Observatory and El Prat-Airport Observatory, and daily precipitation data were provided by the State Meteorological Agency of Spain (AEMET) and the Meteorological Service of Catalonia (SMC). Population data was obtained from the Statistical Institute of Catalonia (IDESCAT). Changes in land use were estimated from the land use maps for Catalonia corresponding to 1956, 1993, 2000, 2005 and 2009. Prevention measures like rainwater tanks and improvements to the drainage system were also been considered. The specific case of Barcelona is presented, a city recognised by UNISDR (United Nations International Strategy for Disaster Reduction) as a model city for urban resilience to floods. The evolution of flood events in the MAB does not show any significant trend for this period. We argue that the evolution in floods can be explained, at least in part, by the lack of trend in extreme precipitation indices, and also by the improvements in flood prevention measures.
\end{abstract}

Keywords: Floods, flash floods, changes in land use, vulnerability, precipitation extremes, Barcelona

\section{Introduction}

Floods are the most dangerous natural hazard in the world, and the risk of floods would increase in a warmer climate, according to the most recent regional and global projections (IPCC, 2012; Hirabayashi et al. 2013). Consequently, improving mitigation and adaptation strategies to cope with floods has become a strategic topic in national (e.g. the Spanish project HOPE, HOlistic analysis of the impact of heavy PrEcipitations and floods and their introduction in future scenarios. Application to adaptation and resilience strategies) and international (e.g. HyMeX: HYdrological cycle in the Mediterranean EXperiment) (Drobinski et al. 2014) climate programmes, and they are a priority in most government agendas (Alfieri et al. 2016).

Yet there are still many uncertainties in characterising the present and future evolution of floods. Recent reports from the IPCC $(2012,2014)$ still show significant uncertainty associated with future projections of extreme precipitation (Turco et al. 2017) and the uncertainties are even greater when considering floods and interaction with society in the context of increased vulnerability. The impacts are exacerbated by the increase in population and in vulnerability, especially in cities where there is already pressure from humans 
(Ceola et al. 2014). This is the case in the Mediterranean region, where the population is concentrated on the coast, often in areas exposed to natural hazards (Eurostat, 2016).

More than 250 events causing floods, flash floods and urban floods have been recorded in Catalonia (Northeast Spain) between 1981 and 2015. The Spanish public reinsurer, the "Insurance Compensation Consortium" (CCS), has paid more than $€ 430$ million in compensation for flooding during the available period of insurance data, 1996-2015. To this amount we must also add the loss of profits and damages to population, as well as all the compensation provided by insurance companies for damages not accepted by the CCS. The coastal zone has the highest number of episodes (70\%), due to highly localised convective rainfall events (Llasat et al. 2016; Gascón et al. 2016). Approximately one third of the episodes affected the regions of Maresme, Barcelonès and Baix Llobregat, which belong, totally or partially, to the Metropolitan Area of Barcelona (MAB). This is an area with significant exposure and vulnerability due to the high population density and concentration of infrastructures (Llasat et al. 2014a). The problem will worsen considering that $70 \%$ of the population will be concentrated in coastal cities by 2050 , according to Benoit and Comeau (2005). In other words, the MAB constitutes a good example of a Mediterranean coastal region, with significant urbanisation of flood prone areas and a high population density in an area crossed by numerous streams.

Several studies have analysed extreme climate and weather events affecting the region of Barcelona (Turco et al. 2014; Llasat et al. 2014b) and the evolution of floods in Catalonia, also considering the evolution of floods over the last six centuries (Barrera-Escoda and Llasat 2015) and over the recent period of 1981-2010 (Llasat et al. 2014a, 2016). For both periods, the extraordinary events show a positive trend, probably linked to land use changes and an increase in assets and dwellings in flood prone areas, leading to an increased flood risk.

However, there is still little known about flood evolution in Mediterranean urban areas, combining drivers and consequences (Faccini et al. 2015). That is, the analysis of flood risk is very complex and needs to be dealt with from a holistic perspective using techniques that take into account all the factors involved, both those related to the dangerous nature of the phenomenon, those related to vulnerability and exposure, and those related to the impacts (Llasat et al. 2009; Blöschl et al. 2013; Nakamura and Llasat, 2017). Most studies analyse the risk of flooding from a top-down perspective, that is, from the nature of the phenomenon while leaving aside other factors. According to Merz et al. (2010) the analysis of flood risk continues to be very unbalanced since, in comparison, much more attention is paid to the dangerousness of the phenomenon than to the impacts it produces. This is why progress is currently being made to incorporate impacts, exposure and vulnerability in the analysis, although limited data (e.g. availability and temporal coverage) makes this challenging (Terti et al. 2015; Karagiorgos et al. 2016; Bodoque et al. 2016).

An approach that addresses the study of floods starting from impacts is called bottom-up (García et al. 2014), and starts on a local scale of individuals, households, and communities, exploring the factors and conditions that enable them to successfully cope with hydrological extremes (Wilby and Dessai 2010). This would be the case for studies carried out in relation to the catastrophic flood episode of 2013 that affected much of Central Europe, which on one hand analyse the hydrometeorological factors that caused the episode (Schröter et al. 2015) and on the other hand analyse the impacts produced (Thieken et al. 2016).

Merz et al. (2010) emphasise the importance of flood risk characterisation from a holistic and multidisciplinary perspective that integrates both approaches. An example of this integrated approach are the studies by Amaro et al. (2010) and Barbería et al. (2014) in which factors related to both dangerousness, vulnerability and exposure are combined to develop social impact indexes. They present the challenge of identifying and improving the assessment of non-hazardous factors (non-climatic factors) and their role in the impact of flood events as indicated by Hall et al. (2014). That is, the key point of these types of analysis is to identify the key factors to be considered when improving strategies for adaptation and mitigation.

In this article we study the evolution of the flood risk in a densely populated area, the MAB, by analysing the different factors related to the hazard, vulnerability and exposure involved, as well as the damages caused. To this end, we first analyse the evolution of flood episodes recorded in the MAB from 1981 to 2015 and the impacts caused. Then, we analyse the changes in land use, runoff, population and 
precipitation extremes in the MAB and their potential relationship with floods. Also, we analyse the link between damages and precipitation over 1996-2015 period, for which CCS data is available. The paper ends with some key conclusions and recommendations.

\section{Region of study}

Catalonia (Figure 1a) is located in the Northwest coast of the Mediterranean Sea. It covers an area of $31,895 \mathrm{~km}^{2}$ (6.3\% of Spain) and has an official population of 7,522,596 (IDESCAT, 2016). The zone selected was the Metropolitan Area of Barcelona (MAB), made up of Barcelona and 35 adjacent municipalities around the city. This urban and peri-urban area has a surface of $636 \mathrm{~km}^{2}$ and a population of 3,239,337. The larger part of the population is concentrated in the municipality of Barcelona $(1,608,746$ people), located between the Besòs River and the Llobregat River, the Littoral Range and the Mediterranean Sea (Figure 1b). Although both rivers have experienced catastrophic flood events (e.g. September 1971) with return periods higher than 100 years, minor flood events occur frequently (every year) as a consequence of convective and local precipitation mainly recorded in late summer and autumn (Llasat et al. 2013; del Moral et al. 2016). Their main impacts are the consequence of drainage and runoff problems and can affect both urban and rural areas.
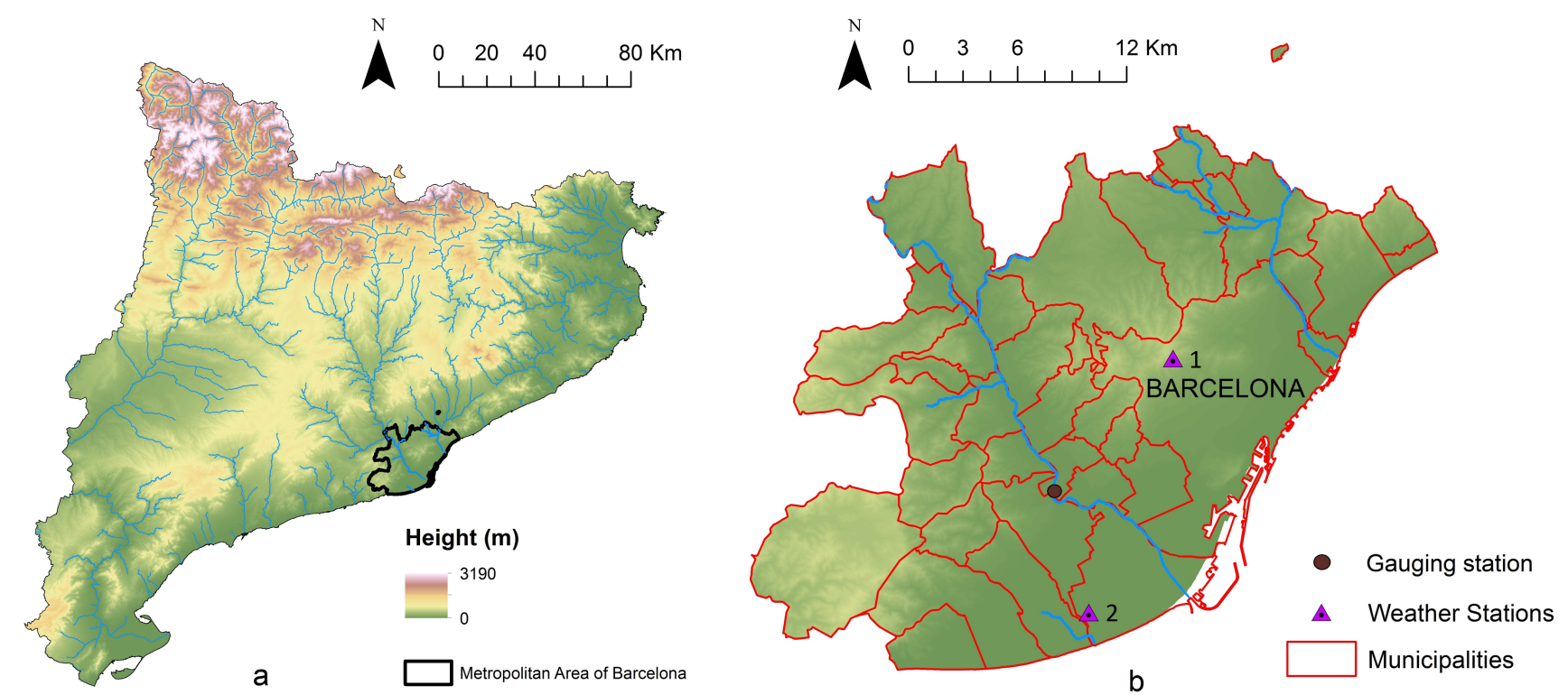

Fig.1 a) Location of Metropolitan Area of Barcelona in Catalonia; b) Map of the Metropolitan Area of Barcelona showing its municipalities, the Sant Joan Despí gauging station and the weather stations (1: Fabra observatory; 2 : International Airport of Barcelona). The Besòs River (the Northern part) and the Llobregat River (the Southern part) are also shown (in blue colour)

In the MAB a total of 109 flood events have been registered for the 1981-2015 period, eight of them causing catastrophic impacts in the region. Most of the catastrophic flood events that affected Barcelona occurred in the 1980s and 1990s, which led to the proposal and construction of the rainwater tanks in the city. On the other hand, due to the construction of the International Airport of Barcelona, the stream of the Llobregat River was altered (Figure 2), and the Besòs River was channelled and modified near its mouth in order to avoid floods and built a fluvial park. A surveillance system was installed in order to warn the population in the case of possible floods.

\section{Data sources}

The analysis uses the INUNGAMA database, which contains more than 200 flood events for all Catalonia for the period 1981-2010 (Barnolas and Llasat 2007; Llasat et al. 2014a), and which was updated until 2015 for this study. The analysis also includes the PRESSGAMA database, which contains more than 15,000 news 
items on natural hazards and climate change published in the newspaper La Vanguardia (Llasat et al. 2009), and updated to cover the period 1981-2015. Information regarding the economic damage caused by floods was provided by the state insurance company "Consorcio de Compensación de Seguros", or CCS, a Spanish national reinsurance company that provides cover for losses caused by significant risks, when covered by the relevant insurance policy. This data is available on a municipal scale for the 1996-2015 period.

Changes in land cover were analysed through the Land Use Maps of Catalonia, drawn up by the Ecological and Forestry Applications Research Centre (Centre de Recerca Ecològica I Aplicacions Forestals, CREAF) for the available editions (1956, 1993, 2000-2002, 2005-2007 and 2009). Runoff coefficients for different land uses were taken from Chow et al. (1988). Population density since 1950 was provided by the Statistical Institute of Catalonia (Institut d'Estadística de Catalunya, IDESCAT). All the cartographic databases were analysed with Arc-Info GIS.

The rainfall data consists of: maps of daily expected precipitation for different return periods in Catalonia (Casas-Castillo et al. 2005); daily rainfall data from the Fabra Observatory (414 MASL) available since 1913, and from the International Airport of Barcelona (El Prat de Llobregat) since 1961 (4 MASL; Figure 1); daily precipitation fields for specific events provided by the Meteorological Service of Catalonia (Servei Meteorològic de Catalunya, SMC) and the State Meteorological Agency of Spain (Agencia Estatal de Meteorología, AEMET). Information related to rainwater tanks was provided by the Barcelona Water Cycle (Barcelona Cicle de l'Aigua, BCASA).

Finally, the cartography with the fluvial network and hazard maps was provided by the Catalan Water Agency (Agència Catalana de l'Aigua, ACA), and also shows the flow data for the Sant Joan Despí station (Llobregat River).

\section{Methodology}

\subsection{Flood event classification}

Flood events have been classified according to their impact (Barriendos et al. 2003; Llasat et al. 2005; Barrera-Escoda et al. 2006; Llasat et al. 2014a). In order to be more specific, we have suggested some indicators, shown in Table 1. This classification allows us to distinguish between three categories: a) ordinary flood events (rivers or streams not overflowing; floods in restricted areas; minor damages, damage to hydraulic infrastructure or cars parked in the temporary flow of the torrential channel; flooded car parks, basements or ground floors; disturbances to daily activities); b) extraordinary flood events (overflowing rivers or streams; some streets or other urban places flooded; damages or partial destruction of structures near the stream or river, damage to street furniture or cars; inconveniences in the daily life of the population); c) catastrophic flood events (overflowing riverbanks; extensive flooded areas; total destruction or serious damage to hydraulic infrastructures (e.g. bridges), buildings, crops, road infrastructures and private assets). In this paper the classification was applied on four levels: first, with regard to the impact throughout Catalonia as a whole; second, according to the impact in the MAB; third, in the MAB without taking into account Barcelona; fourth, in the Barcelona municipality. 
Table 1 Indicators to determine the impact of each flood event

\begin{tabular}{|c|c|c|c|c|}
\hline Indicator & Definition & Catastrophic event & Extraordinary event & Ordinary event \\
\hline Public buildings & $\begin{array}{l}\text { City hall, hospital, } \\
\text { school, church, } \\
\text { emergency centres, } \\
\text { police station, etc. }\end{array}$ & $\begin{array}{c}\text { Total destruction or } \\
\text { collapse }\end{array}$ & $\begin{array}{l}\text { Partial destruction } \\
\text { or structural } \\
\text { damage }\end{array}$ & Flooded, habitable \\
\hline Private houses & $\begin{array}{l}\text { Houses with one or more } \\
\text { floors, basements, etc. }\end{array}$ & $\begin{array}{c}\text { Total destruction or } \\
\text { collapse }\end{array}$ & \begin{tabular}{|c|} 
Partial destruction \\
or structural \\
damage
\end{tabular} & Flooded, habitable \\
\hline Bridges & Bridges, footbridges & $\begin{array}{l}\text { Destroyed, } \\
\text { unusable }\end{array}$ & $\begin{array}{c}\text { Structural damage, } \\
\text { unusable bridges or } \\
\text { damage to } \\
\text { footbridges }\end{array}$ & Usable \\
\hline $\begin{array}{c}\text { Hydraulic } \\
\text { infrastructures }\end{array}$ & Mills, irrigation channels & Destroyed & Medium damage & Minor damage \\
\hline Roads & $\begin{array}{c}\text { Railway, highway, state } \\
\text { road, country road, } \\
\text { regional road, municipal } \\
\text { road }\end{array}$ & $\begin{array}{l}\text { Partially destroyed, } \\
\text { one or more } \\
\text { stretches of the } \\
\text { road damaged }\end{array}$ & $\begin{array}{c}\text { Flooded, closed for } \\
>12 \text { hours }\end{array}$ & $\begin{array}{c}\text { Flooded, closed } \\
\text { between } 0 \text { and } 12 \\
\text { hours or not closed }\end{array}$ \\
\hline Services & $\begin{array}{l}\text { Gas, electricity, } \\
\text { telephone lines, water }\end{array}$ & $\begin{array}{l}\text { Destruction and/or } \\
\text { closure of } \\
\text { infrastructures for } \\
>24 \mathrm{~h}\end{array}$ & $\begin{array}{l}\text { Closed between } 6 \\
\text { and } 24 \text { hours }\end{array}$ & Closed for $<6$ hours \\
\hline Productive activities & $\begin{array}{l}\text { Industry, agriculture and } \\
\text { livestock, commerce, } \\
\text { touristic infrastructures }\end{array}$ & $\begin{array}{c}\text { Interruption of } \\
\text { production and loss } \\
\text { of the production } \\
\text { system }\end{array}$ & $\begin{array}{c}\text { Interruption of } \\
\text { production and loss } \\
\text { of products }\end{array}$ & Loss of products \\
\hline Cars & $\begin{array}{l}\text { Cars washed away or } \\
\text { damaged by water }\end{array}$ & $\begin{array}{c}20 \text { or more washed } \\
\text { away }\end{array}$ & $\begin{array}{c}\text { Between } 5 \text { and } 19 \\
\text { washed away }\end{array}$ & $\begin{array}{c}\text { Between } 1 \text { and } 4 \\
\text { damaged and/or } \\
\text { washed away }\end{array}$ \\
\hline Deaths & No. of people dead & 10 or more & Between 5 and 9 & Between 1 and 4 \\
\hline
\end{tabular}

\subsection{Land cover evolution}

The available maps (Table 2) have been homogenised following the characteristics of the first edition of the Land Cover and Land Use map (LCLU-I). The oldest edition of the LCLU was based on American flight photos made in 1956 over the Barcelona province. It was recently processed and for this reason includes 241 categories like the later editions. LCLU-1956, LCLU-III and LCLU-IV use a hierarchical legend with 5 levels of categories. In order to compare the different time editions and analyse the evolution of land use, all the maps have been homogenised in a common resolution of $2.5 \mathrm{~m} \times 2.5 \mathrm{~m}$ and have been classified using 24 categories as used in LCLU-I.

Table 2 Features of the LCLU (Land Cover and Land Use maps of Catalonia) for each edition

\begin{tabular}{|l|r|r|r|r|r|}
\hline Edition & \multicolumn{1}{l|l}{ LCLU-1956 } & \multicolumn{1}{l|l}{ LCLU-I } & \multicolumn{1}{l|}{ LCLU-II } & \multicolumn{1}{l|}{ LCLU-III } & \multicolumn{1}{l|}{ LCLU-IV } \\
\hline Year & 1956 & 1993 & $2000-02$ & $2005-07$ & 2009 \\
\hline Orthophotos scale & $1: 25,000$ & $1: 25,000$ & $1: 5,000$ & $1: 5,000$ & $1: 2,500$ \\
\hline Resolution (pixel) & $2.5 \mathrm{~m}$ & $2.5 \mathrm{~m}$ & $0.5 \mathrm{~m}$ & $0.5 \mathrm{~m}$ & $0.25 \mathrm{~m}$ \\
\hline Working scale & $1: 3,000$ & $1: 3,000$ & $1: 1,500$ & $1: 1,500$ & $1: 1,000$ \\
\hline Categories & 241 & 24 & 61 & 241 & 241 \\
\hline
\end{tabular}


Taking into account the heterogeneity of the region and its hydraulic features, a streamlined method has been applied to estimate the runoff, based on the application of the runoff coefficients proposed by Chow et al. (1988) for different return periods. Taking into account that the average slope in the MAB is between $2 \%$ and $7 \%$, we considered that runoff coefficients only depend on the return period (Table 3 ). The 24 initial categories of the LCLU have been merged into 7 categories according to land permeability, in order to avoid the dispersal that excess categories would cause.

Table 3 Runoff coefficients for each category and return period (Chow et al. 1988)

\begin{tabular}{|c|c|c|c|c|c|c|c|c|}
\hline \multicolumn{8}{|c|}{ Runoff Coefficients } & \multirow{3}{*}{ LCLU categories } \\
\hline \multirow{2}{*}{ Permeability categories } & \multicolumn{7}{|c|}{ Return Periods } & \\
\hline & 2 & 5 & 10 & 25 & 50 & 100 & 500 & \\
\hline Lakes & 0 & 0 & 0 & 0 & 0 & 0 & 0 & $\begin{array}{l}\text { Wetlands, beaches, water, canals } \\
\text { and ponds, urban ponds }\end{array}$ \\
\hline High perviousness & 0.31 & 0.34 & 0.36 & 0.40 & 0.43 & 0.47 & 0.57 & $\begin{array}{l}\text { Forest (dense, not dense, } \\
\text { riverside) }\end{array}$ \\
\hline Moderate perviousness & 0.33 & 0.36 & 0.38 & 0.42 & 0.45 & 0.49 & 0.58 & Meadows, bushes \\
\hline Low perviousness & 0.35 & 0.38 & 0.41 & 0.44 & 0.48 & 0.51 & 0.6 & $\begin{array}{l}\text { Crops, Populus and Platanus } \\
\text { plantations }\end{array}$ \\
\hline Low imperviousness & 0.35 & 0.39 & 0.41 & 0.45 & 0.48 & 0.52 & 0.58 & $\begin{array}{l}\text { Recent reforestation, burned } \\
\text { areas, forest tracks and firebreaks }\end{array}$ \\
\hline Moderate imperviousness & 0.40 & 0.43 & 0.45 & 0.49 & 0.52 & 0.55 & 0.62 & $\begin{array}{l}\text { Vacant lots, sport and recreational } \\
\text { areas }\end{array}$ \\
\hline High imperviousness & 0.74 & 0.78 & 0.82 & 0.87 & 0.91 & 0.96 & 1 & $\begin{array}{l}\text { Scree slopes, snowdrifts and } \\
\text { glaciers, urban areas, roads and } \\
\text { train tracks, mines }\end{array}$ \\
\hline
\end{tabular}

Each layer has been classified in a category with an assigned runoff coefficient. All this information has been aggregated on a municipal scale as the average of all the pixels. Consequently, each municipality is characterised by the previously selected return periods and a runoff coefficient, calculated using the average of all the pixels included in it. Although it only provides an approximate runoff, this approach is typical in urban public works and helps to improve estimates for running or accumulated water that can affect exposed assets and the population in general. The advantage is that it can be used in regional analysis.

Following this methodology, the return periods for rainfall have also been obtained on a municipal scale from the maps of maximum daily precipitation expected in Catalonia for different return periods (CasasCastillo et al. 2005). The return period corresponding to the flow for each specific flood event has been calculated through GEV (Generalised Extreme values) with a regional value of L-Coefficient of skewness (Mediero et al. 2010).

\subsection{Flood and rainfall analysis}

In order to analyse the flood and rainfall evolution, we carried out analysis on trend significance using the Mann Kendall test (Mann 1945; Kendall 1975), with a threshold of significance established at $95 \%$ and $90 \%$ ( $p$-value $<0.05$ and $p$-value $<0.1$ respectively). For flood events, we studied the annual evolution of the total number of floods as well as the floods in different categories (ordinary, extraordinary and catastrophic) for the period 1981-2015. Furthermore, a monthly and seasonal analysis was carried out.

To analyse the specific case of the city of Barcelona and the impact of the preventive measures taken in the city on flood evolution, a study was carried out for three different scenarios: MAB, Barcelona and MAB without Barcelona. For precipitation data we used the values recorded in $24 \mathrm{~h}$ as well as the rainfall accumulation for the whole episode (obtained from AEMET stations). In order to analyse the data in a 
comparable way, we considered a subset of the "moderate and extreme" precipitation indices defined by the World Meteorological Organization (WMO, 2009) CC1/CLIVAR/JCOMM Expert Team on Climate Change Detection and Indices (ETCCDI). More specifically, the chosen subsets of indices (Table 4) summarise the behaviour of precipitation, describing some standard indices such as the total precipitation (PRCPTOT) and precipitation intensity (SDII), as well as two extreme indices related to critical consequences, such as the highest precipitation amount over a one or five-day period (RX1DAY and RX5DAY, respectively).

The comparison between flood events and their drivers were carried out considering the periods 19811996, 1996-2015 and 1981-2015, given that CCS data is only available for the 1996-2015 period. For each of these periods we calculated: the trend in the number of total events, the trend according to flood impact categories, and the trend for maximum precipitation recorded in one day (RX1DAY) for both the Fabra and Airport observatories. To calculate the changes in land use while taking into account the land permeability categories, the LCLU-1956 map was considered to represent the starting point. Attending that there is not any new information about land uses changes until 1993, the percentage of impervious surface in the MAB in 1981 was interpolated from LCLU-1956 and LCLU-1993 maps. The LCLU-1993 was considered as representative for the 1996 land use coverage and the LCLU-2009 map shows 2015 coverage.

Table 4 Selected ETCDDI indices

\begin{tabular}{|c|l|}
\hline ETCCDI & \multicolumn{1}{c|}{ Description } \\
\hline PRCPTOT & Total precipitation \\
\hline SDII & Mean precipitation amount per rainfall day \\
\hline RX1DAY & Maximum precipitation in one day \\
\hline RX5DAY & Maximum accumulated precipitation in five days \\
\hline
\end{tabular}

In order to carry out a more detailed analysis, we selected 10 extraordinary and 3 catastrophic flood episodes in the MAB between 1996 and 2015, considering their individual impact in each one of the 36 municipalities. Table 5 shows the episodes studied along with their start/end dates and their category (according to their impact). For each episode the average precipitation values on a municipal level were obtained through ordinary Kriging with ArcGIS. In order to obtain the daily runoff values, the runoff coefficient on a municipal level (the average from the runoff categories for the different pixels) was multiplied by the accumulated daily precipitation. The correlation analysis was achieved using the Spearman test and the results are discussed in section 5.6 (Table 9).

Table 5 Flood events recorded in the MAB when CCS data is available (1996-2015)

\begin{tabular}{|l|l|l|}
\hline Start date & End date & Event category \\
\hline $02 / 12 / 1998$ & $04 / 12 / 1998$ & Extraordinary \\
\hline $03 / 09 / 1999$ & $04 / 09 / 1999$ & Extraordinary \\
\hline $13 / 09 / 1999$ & $15 / 09 / 1999$ & Extraordinary \\
\hline $10 / 06 / 2000$ & $12 / 06 / 2000$ & Extraordinary \\
\hline $31 / 07 / 2002$ & $02 / 08 / 2002$ & Extraordinary \\
\hline $10 / 08 / 2002$ & $11 / 08 / 2002$ & Extraordinary \\
\hline $12 / 09 / 2002$ & $14 / 09 / 2002$ & Extraordinary \\
\hline $08 / 10 / 2002$ & $11 / 10 / 2002$ & Catastrophic \\
\hline $05 / 09 / 2005$ & $09 / 09 / 2005$ & Catastrophic \\
\hline $12 / 09 / 2006$ & $15 / 09 / 2006$ & Catastrophic \\
\hline $22 / 10 / 2009$ & $23 / 10 / 2009$ & Extraordinary \\
\hline $30 / 07 / 2011$ & $31 / 07 / 2011$ & Extraordinary \\
\hline $28 / 09 / 2014$ & $01 / 10 / 2014$ & Extraordinary \\
\hline
\end{tabular}




\subsection{The evolution of Societal Impact}

The social impact analysis was carried out using the compensation provided for flood damages as registered in the CCS dataset. This data has the advantage that is taken directly from a municipal level, spanning the period from 1996-2015. However, working with a damage-cost time-series involves taking into account changes in living standards, as well as the different economic trends applied to insured assets (Barredo et al. 2012). Thus, we updated the currency to transfer the damage values to euros, taking the year 2015 as our reference point (Instituto Nacional de Estadística, INE). We considered the compensation paid by the CCS during the flooding episodes and, also, during the following 7 days after their conclusion (this is the period accepted by the CCS to report flood related losses). The variables used were: total damages, the ratio of total damages/population density, and the ratio between total damages/population. The temporal evolution of the compensations paid by CCS was also analysed, along with the correlation between damages/precipitation and damages/runoff for the 13 specific cases.

\section{Results and discussion}

\subsection{Influence of land use changes in runoff}

The comparison between the impervious/pervious maps based on LCLU maps show how the majority of the agricultural soil (low perviousness) has been substituted by urban surfaces (high imperviousness) between the first (1956) and the last map (2009; Figure 2). There is not so much change in this period in the area covered by forests (approximately, 25\%), which mainly corresponds to the Tibidabo Mountain, with a maximum altitude of $505 \mathrm{~m}$. Instead, the agricultural area has diminished around 80\% between 1956 and 2009 , being replaced by urban surfaces and the road network (increase of more than $225 \%$ ). However, the difference between 1993 and 2009 is lower, with a decrease of the agricultural area near $47 \%$ and an increase of the urban surfaces and the road network around $20 \%$. Consequently, the urban surfaces and impermeable soil have not increased so significantly over the last few years and have only gone from $36.5 \%$ coverage in 1993 to $43.4 \%$ in 2009.

For the 1950-2015 period the population has increased from 1,555,236 to 3,213,775 inhabitants. The population peak in the MAB was recorded in the ' 80 s, and afterwards began to decline until the currently situation. This changing point does not match with the general trend in Catalonia or in Spain, which recorded a maximum at the end of the first decade of the $21^{\text {st }}$ century. The major housing price increases in the $M A B$ and the economic crisis are the main explanations for these turning points, as well as negative trends in population growth. 

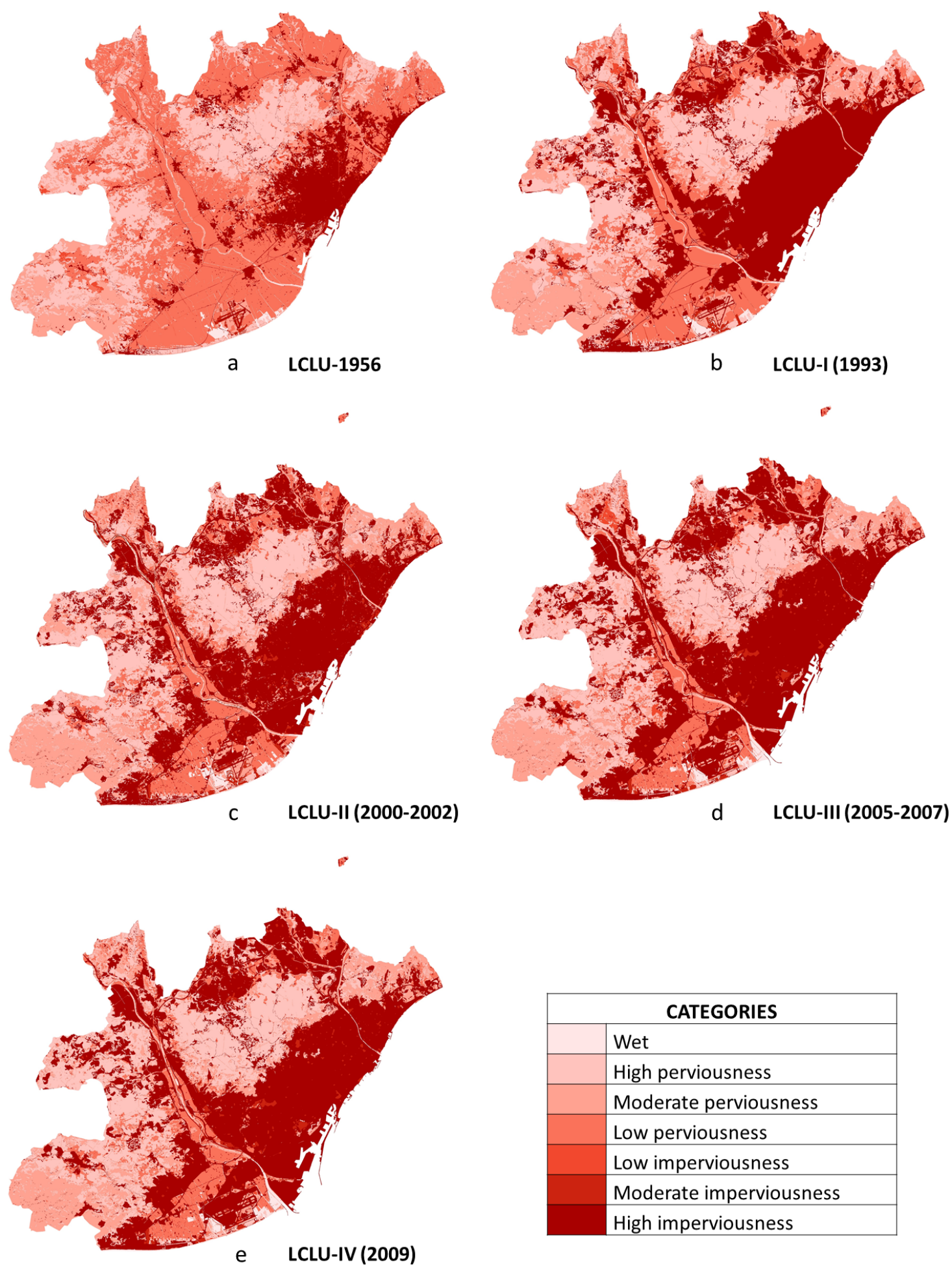

\begin{tabular}{|l|l|}
\hline \multicolumn{2}{|c|}{ CATEGORIES } \\
\hline & Wet \\
\hline & High perviousness \\
\hline Moderate perviousness \\
\hline Low perviousness \\
\hline Low imperviousness \\
\hline Moderate imperviousness \\
\hline High imperviousness \\
\hline
\end{tabular}

Fig. 2 Comparison between the impervious/pervious maps based on the five different LCLU maps considering 7 categories: a) LCLU (1956); b) LCLU-I (1993); c) LCLU-II (200-2002); d) LCLU-III (2005-2007); e) LCLU-IV (2009)

Figure 3 shows the runoff changes for a $24 \mathrm{~h}$ rainfall return period over 100 years for the different LCLU maps. As expected, there is an increase in average runoff for all municipalities, due to the increase in impermeable soil (a feature that can be already observed in Figure 2). In most municipalities (67\%) between 1956 and 2009, there was an increase in runoff of over $20 \%$, with an average of $30 \%$ for the MAB. 
In Barcelona, the runoff increase stands at $19 \%$ for this period (without considering the improvements in sewerage systems and flood prevention infrastructures that were introduced in the 1990s). Figure 4 shows the evolution of the average runoff in the MAB and Barcelona, along with the installation of the first rainwater tank. This figure brings together the major changes that occurred between 1956 and 1993 due to the significant industrialisation of the region, which was the location of the majority of the textile industry in Spain during this period.
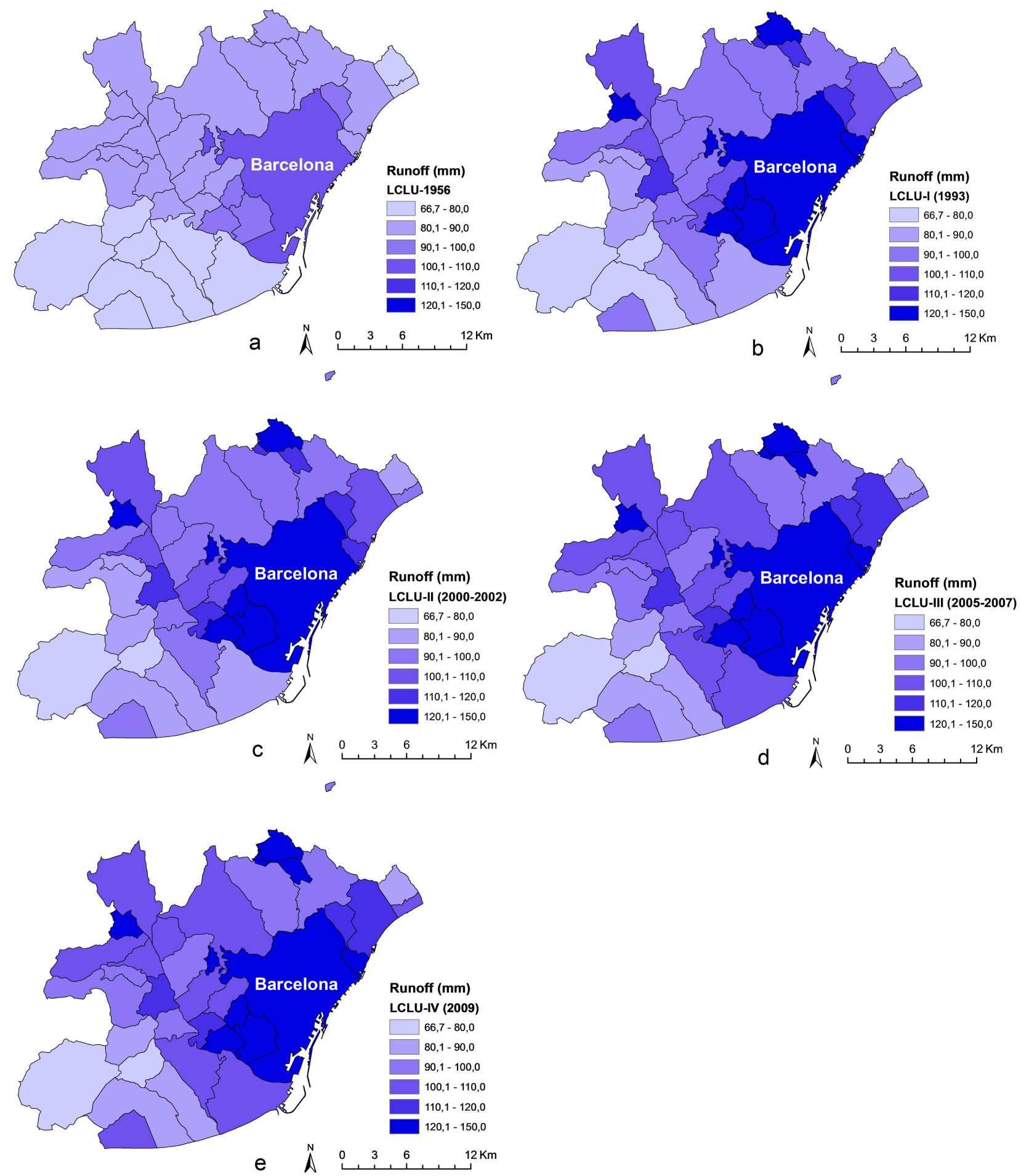

Fig. 3 Mean runoff on a municipal level for a return period showing daily precipitation over 100 years, taking into account the runoff coefficients in Table 3: a) LCLU (1956); b) LCLU-I (1993); c) LCLU-II (2000-2002); d) LCLU-III (20052007); e) LCLU-IV (2009) 


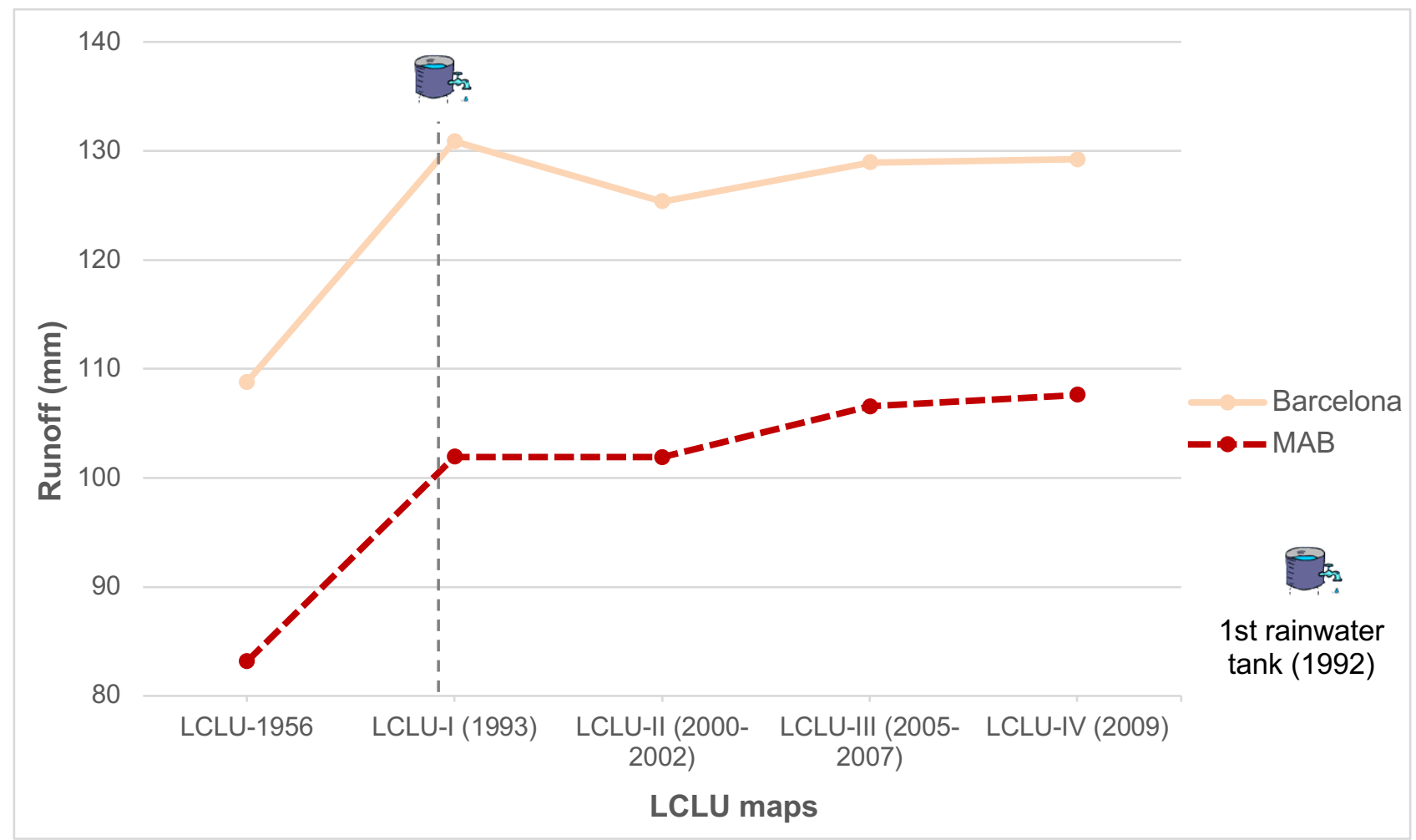

Fig. 4 The evolution of the mean runoff in the MAB and Barcelona for a return period of 100 years, based on the five different LCLU maps. The date of construction of the first rainwater tank in Barcelona is also shown

\subsection{Rainfall evolution}

Figure 5 shows the evolution of the selected ETCDDI indices for the rainfall measured in the Fabra Observatory. Although all the series show a negative trend for the 1981-2015 period, they are not statistically significant at $95 \%$ or $90 \%$. On the other hand, the PCRPTOT, SDII and RX5DAY indices show a significant negative trend ( $p$-value<0.1) at the Airport weather station. This heterogeneity is normal for the region as shown in the last report on Climate Change in Catalonia (Martin Vide et al. 2016). 


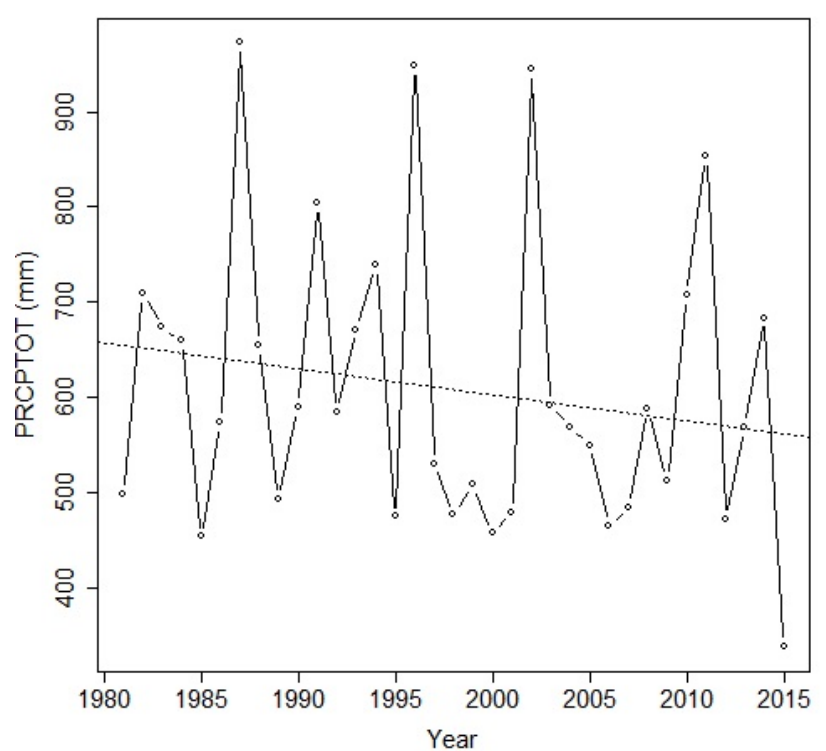

a

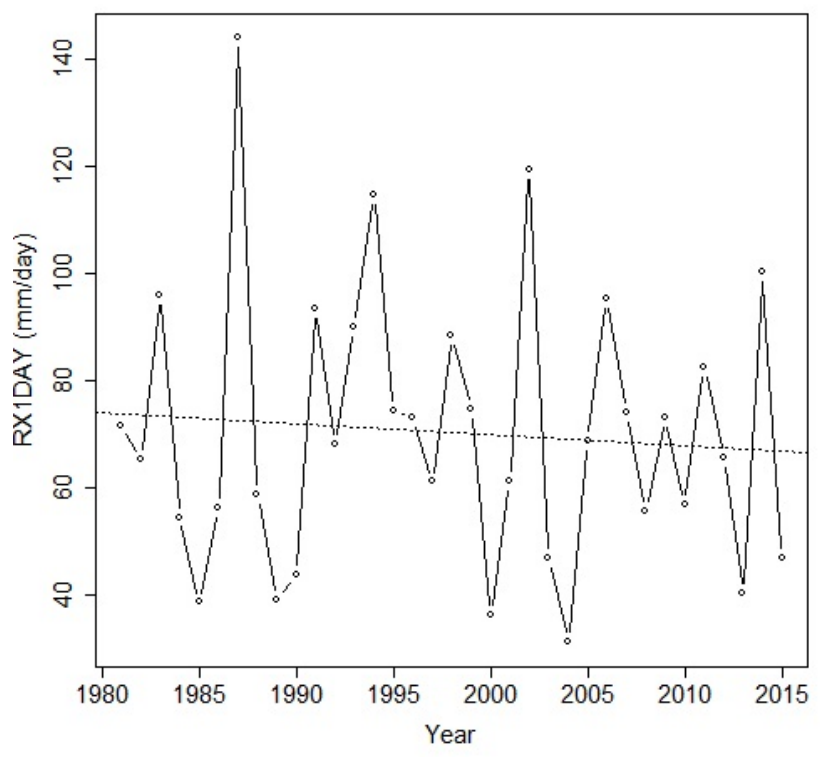

C

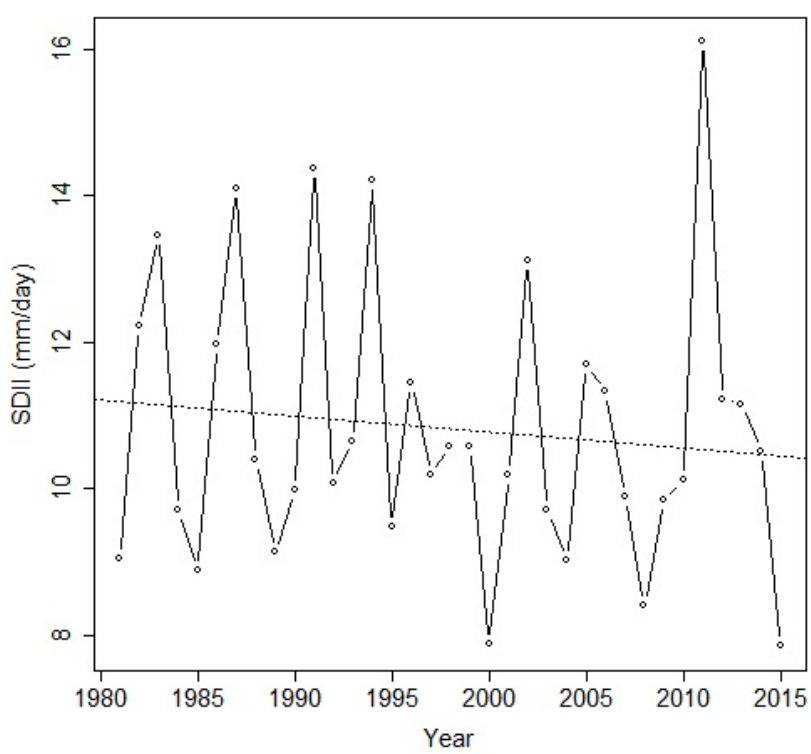

b

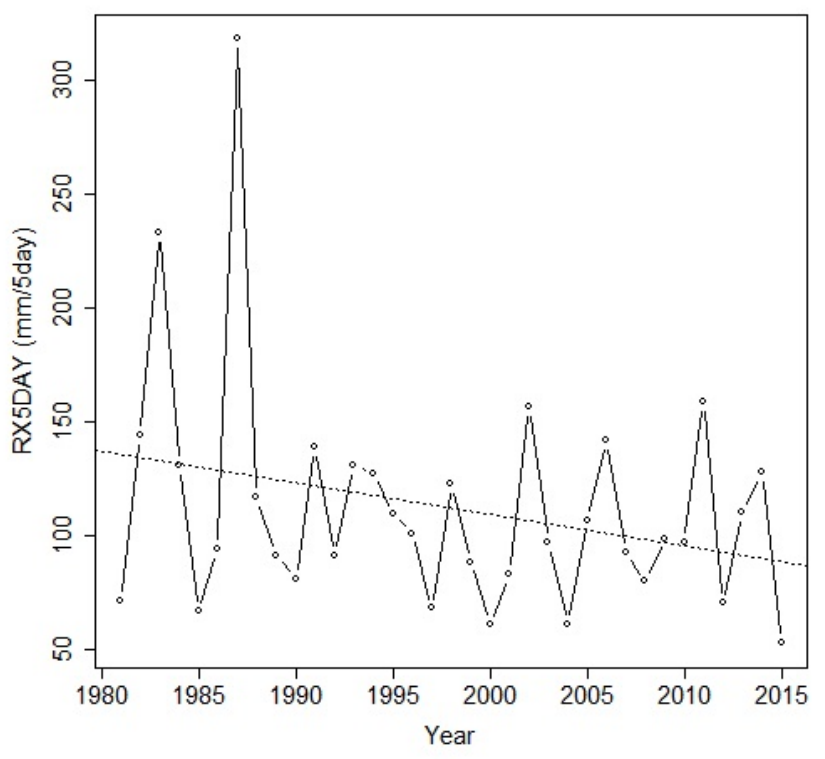

d

Fig. 5 Evolution of the ETCCDI indices (according to table 4) for the Fabra station: a) PRCPTOT index (mm); b) SDII (mm/day); c) RX1DAY (mm/day); RX5DAY (mm/5days)

Table 6 Trend analysis results for ETCCDI indices for the Airport and Fabra weather stations

\begin{tabular}{|l|r|l|r|r|}
\hline \multicolumn{5}{|c|}{ AIRPORT } \\
\hline & PRCPTOT & SDII & RX1DAY & RX5DAY \\
\hline Trend (unit/year) & $-5.44^{* *}$ & $-0.08^{*}$ & -0.60 & $-2.08^{*}$ \\
\hline \multicolumn{7}{|c|}{ FABRA } \\
\hline & PRCPTOT & SDII & RX1DAY & RX5DAY \\
\hline Trend (unit/year) & -2.74 & -0.02 & -0.20 & -1.38 \\
\hline
\end{tabular}

*p-value $<0.1 ; * *$-value $<0.05$ 


\subsection{Flood evolution}

MAB has been affected by 109 flood events in the period 1981-2015, concentrated in the coastal municipalities and in the Llobregat river axis (Barcelona recorded the most flood events at 73 events, followed by Castelldefels, near the Airport, with 24 events). Of the 109 events, 19 caused catastrophic impacts in Catalonia and 50\% also produced catastrophic damages in the MAB. As a consequence of these floods, 11 people lost their lives: 5 deaths were caused by ordinary events; 1 by extraordinary events and 5 by catastrophic events.

The monthly evolution of flood events shows maximum levels between August and October, with a peak in September that records $29 \%$ of the total; $26 \%$ were extraordinary events and $13 \%$ were catastrophic events. Usually these are local flash floods and urban floods associated with heavy and short rainfall events (Llasat et al. 2016). In Barcelona theses values decreased from $23 \%$ and $9 \%$ respectively. This means that $68 \%$ of the events are considered ordinary events, suggesting the positive role played by rainwater tanks in reducing high-impact flood events.

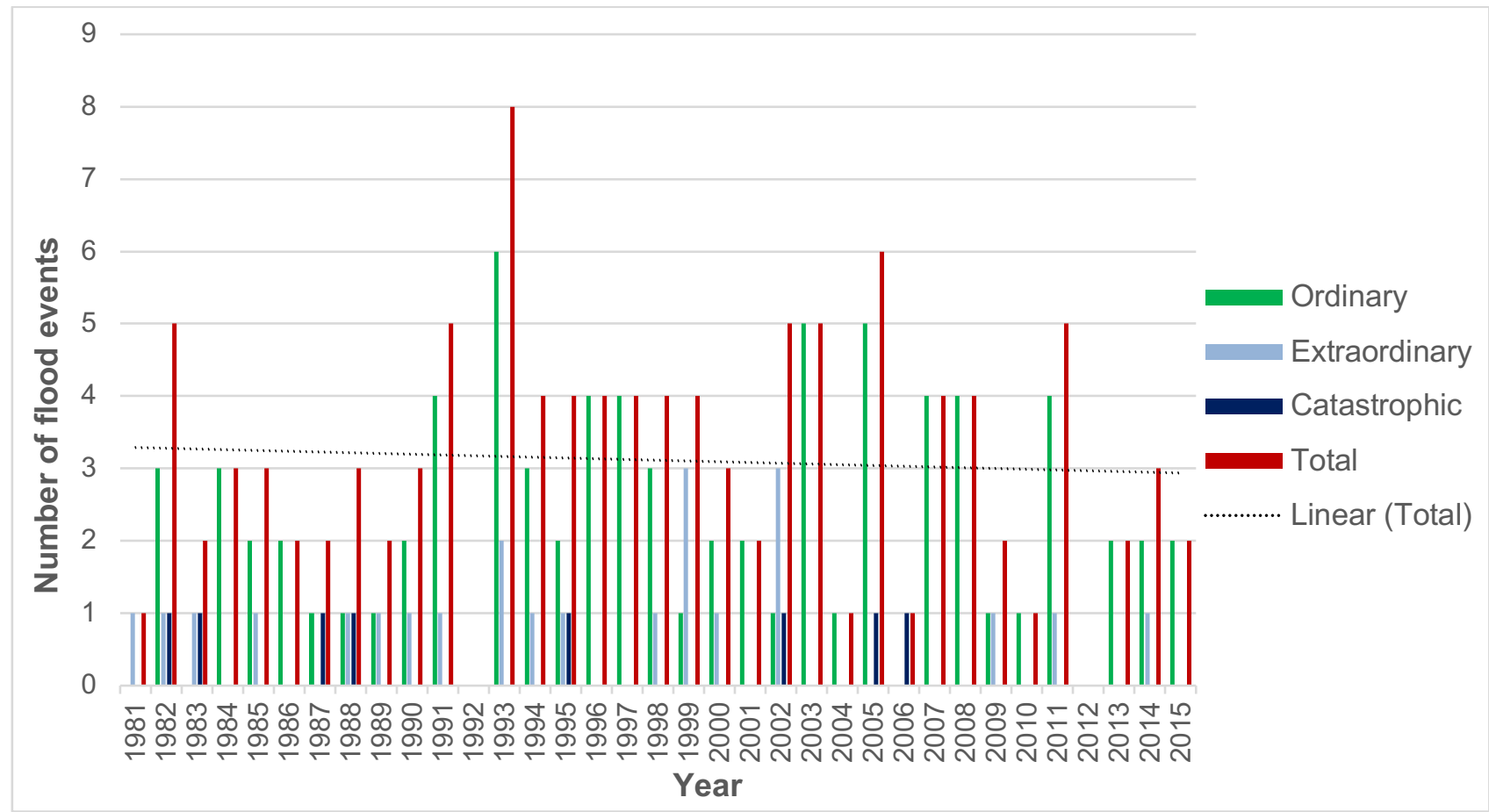

Fig. 6 Number of flood events in the MAB (1981-2015), according to their impact category

Figure 6 shows the evolution of flood episodes in the MAB for the 1981-2015 period. The trends for the three categories are generally negative, although none of them are statistically significant $(p<0.05)$. On the other hand, a positive trend of total events ( 0.08 events/decade) was shown for September, although it is not significant at $90 \%$. The detailed analysis of both the MAB series with and without Barcelona, shows that this negative trend is a consequence of the strong weight of the Barcelona municipality. In effect, although the MAB series without Barcelona shows a positive but not a significant trend, the flood evolution in Barcelona shows a negative and significant trend (Table 7). This fact is consistent with the efficiency of drainage infrastructures in reducing and mitigating the flood impact of high intensity events and the amount of precipitation in the city (Barrera-Escoda et al. 2006). The drainage network together with the rainwater tanks and the warning system for the Besòs river meant that Barcelona received acknowledgment from UNISDR (United Nations International Strategy for Disaster Reduction) as a model city for urban resilience to floods (UNISDR 2015b). 
Table 7 Trend analysis result for the number of flood events in the MAB, Barcelona and the MAB without Barcelona

\begin{tabular}{|l|c|r|r|r|}
\hline \multicolumn{5}{|c|}{ METROPOLITAN AREA OF BARCELONA } \\
\hline & TOTAL & ORDINARY & EXTRAORDINARY & CATASTROPHIC \\
\hline Trend (unit/decade) & -0.10 & 0.15 & -0.15 & -0.10 \\
\hline \multicolumn{7}{|c|}{ BARCELONA } \\
\hline Trend (unit/decade) & -0.18 & 0.11 & $-0.20^{*} *$ & $-0.08^{*}$ \\
\hline \multicolumn{7}{|c|}{ METROPOLITAN AREA OF BARCELONA WITHOUT BARCELONA } \\
\hline Trend (unit/decade)
\end{tabular}

* p-value $<0.1 ; * *$-value $<0.05$

\subsection{Damage evolution}

Figure 7 shows the annual changes in compensation for floods paid by the CCS in the MAB between 1996 and 2015 , as well as the total number of recorded flood episodes for this period. The compensation paid by the CCS shows significant variability from one year to another and no trends were found. For instance, in 1999 nearly $€ 34.8$ million was paid as a consequence of two events, when the annual average is $€ 4.3$ million. In 2002 there were a total of 5 episodes, one of which was catastrophic and 3 of which were extraordinary, with a total amount of $€ 26.6$ million. The total amount paid by the CCS due to floods produced in MAB between 1996 and 2015 is $€ 86.3$ million. The municipality of Barcelona has the maximum record with $€ 24$ million. There is a strong inter-annual variability for the number of annual news items published in La Vanguardia, which recorded 43 news items on floods produced in the MAB for the year 1999. During 13-14 September of 1999 an extraordinary flood event took place as a consequence of a heavy precipitation that produced more than $43 \mathrm{~mm}$ in $30 \mathrm{~min}$, and a maximum flow of the Llobregat River (at the Sant Joan Despí gauge) of $197.3 \mathrm{~m}^{3} / \mathrm{s}$ (the average is around $20 \mathrm{~m}^{3} / \mathrm{s}$ ) corresponding to a return period of 2.2 years. Despite the strong variability, a positive correlation of 0.43 (significant at $90 \%$ ) was observed between the annual number of episodes and annual damages. 


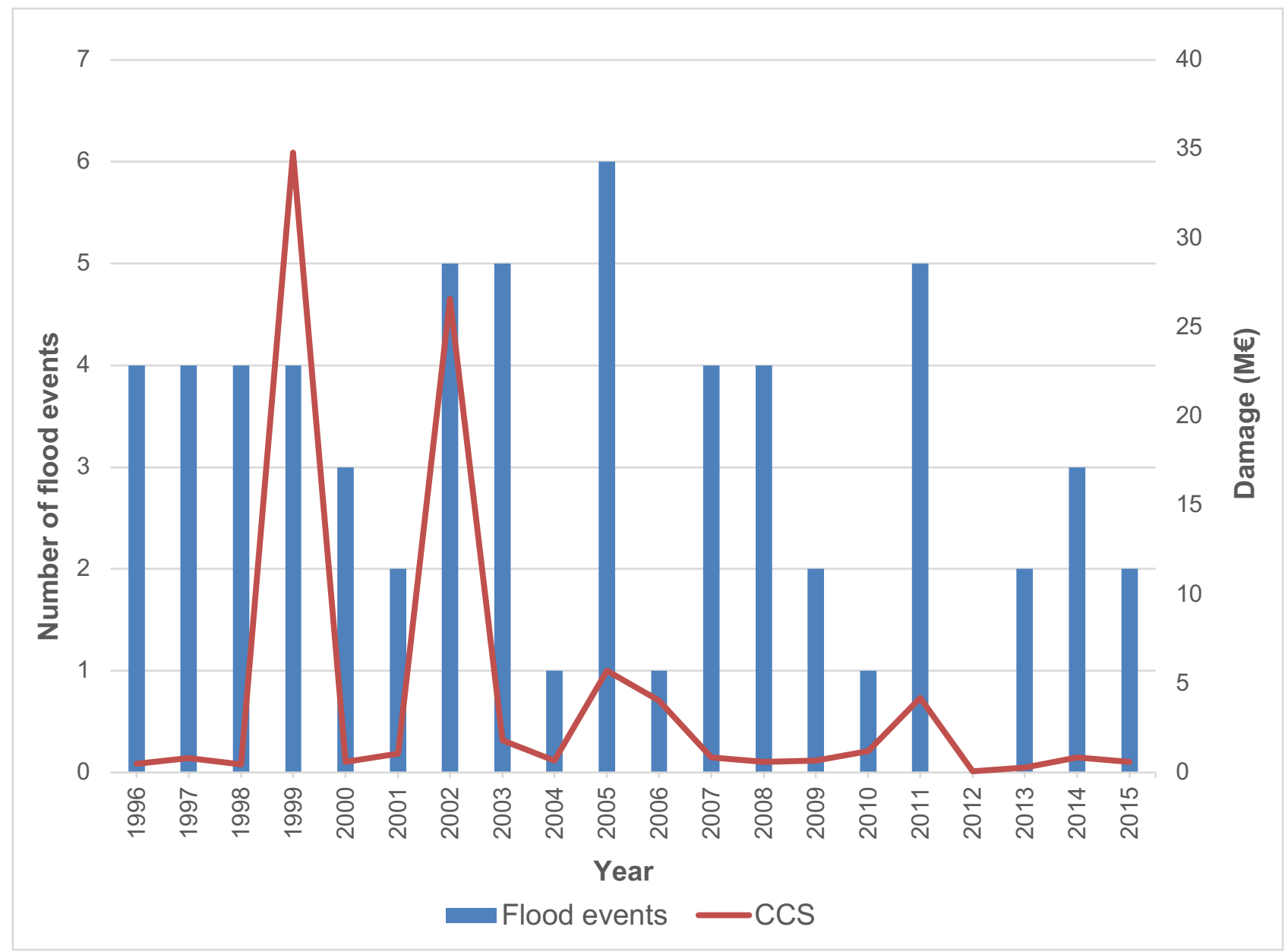

Fig. 7 Evolution of the compensation paid by CCS for floods (line) and the total number of flood events in the MAB

\subsection{Floods versus land cover and rainfall}

In this section, we carried out an analysis of different time periods to look for the potential relationships between flood episodes and the factors that produce them. The results obtained are shown in Table 8 . There are no significant changes in either the number of flood episodes or the maximum one-day precipitation (RX1DAY) for any period (1981-2015; 1981-1996; 1996-2015). In the 1981-1996 period there is a positive trend in the number of flood events, although it is not statistically significant. This positive trend would be due to the increase in ordinary floods. This could be mainly related to the urban development in this period ( $25.81 \%$ of new impervious surfaces) and the increase in the maximum precipitation registered in a single day (Table 8). Conversely, for the 1996-2015 period, although there was an increase in impermeable surfaces (around 20\%), there was a decrease in the number of flooding episodes, as well as in extreme precipitation. For the 1981-2015 period, the increase in impermeable surfaces was significant (more than 50\%), which caused an increase in average runoff (Fig. 4). However, the results do not show any significant trends in the number of flood episodes for the 1981-2015 period. These results show the complexity of flood risk analysis, where many factors intervene simultaneously to either favour or impede flooding. In the case of Barcelona, after an unexpected heavy rainfall event recorded in September 1996, CLABSA (the company that carried out the sewer system of Barcelona, nowadays BCASA) developed a sophisticated strategy to cope with floods. This planning included building rainwater tanks and a permanent monitoring system. 
Table 8 Flood events, imperviousness and RX1DAY for different periods

\begin{tabular}{|c|c|c|c|c|c|c|c|}
\hline \multirow[t]{2}{*}{ Period } & \multicolumn{4}{|c|}{$\begin{array}{l}\text { Flood evolution trend in } \\
\text { MAB (No/decade) }\end{array}$} & \multirow{2}{*}{$\begin{array}{l}\text { Increase high imperviousness } \\
\text { land cover MAB (\%) }\end{array}$} & \multicolumn{2}{|c|}{$\begin{array}{l}\text { RX1DAY trend } \\
\text { (mm/year) }\end{array}$} \\
\hline & TOT & ORD & EXT & CAT & & Airport & Fabra \\
\hline 1981-1996 & 1.40 & 1.56 & 0.06 & -0.22 & 25.82 & 1.38 & 1.08 \\
\hline 1996-2015 & -1.10 & -0.66 & -0.38 & -0.05 & 19.56 & -0.47 & -0.24 \\
\hline $1981-2015$ & -0.10 & 0.15 & -0.15 & -0.10 & 50.42 & -0.60 & -0.20 \\
\hline
\end{tabular}

*p-value $<0.1 ; * *$-value $<0.05$

\subsection{Damage versus runoff and precipitation}

In this section, we analysed the possible correlation between flood damage, precipitation and runoff for the extraordinary and catastrophic flood episodes that affected the MAB between 1996 and 2015. We considered the following variables: precipitation over $24 \mathrm{~h}$, accumulated precipitation for the entire duration of the episode, runoff, total damage, damage relative to population density and damage relative to total population of the municipality. Correlation with damages was carried out for all the events, for the events in which precipitation in $24 \mathrm{~h}$ exceeded the return period of 2 years, and for events in which accumulated precipitation surpassed $100 \mathrm{~mm}$.

First of all, we only considered cases that caused catastrophic impacts in the MAB, before looking at all the extraordinary and catastrophic events documented in the region. Table 9 summarises the results obtained for catastrophic cases, highlighting the larger correlation values. In all cases, the correlations were significant at $95 \%$ using the Spearman test. As it can be observed, correlations with damages are always better with runoff than with precipitation. This result may be explained by the stream's impact in flood damages and suggest the importance of the type of soil cover as a determining factor in the analysis of flood risk. 
Table 9 Correlation values between damage (CCS), precipitation and runoff for catastrophic flood events for the 19962015 period (with available CCS data). The best results are in bold

\begin{tabular}{|c|c|c|c|}
\hline & $\begin{array}{l}\text { Total damage } \\
\text { (millions of } € \text { ) }\end{array}$ & $\begin{array}{c}\text { Damage/population } \\
\text { density }(€ / \text { inhab·km-2 })\end{array}$ & $\begin{array}{l}\text { Damage/population } \\
\text { (€/inhab) }\end{array}$ \\
\hline Precipitation $24 \mathrm{~h}(\mathrm{~mm})$ & $0.19 * *$ & $0.22 * *$ & $0.26 * *$ \\
\hline $\begin{array}{l}\text { Precipitation } 24 \mathrm{~h}(\mathrm{~mm}) \text { with } \mathrm{T}>2 \\
\text { years }\end{array}$ & $0.33^{* *}$ & $0.36 * *$ & $0.46 * *$ \\
\hline Accumulated precipitation $(\mathrm{mm})$ & $0.23 * *$ & $0.23^{* *}$ & $0.29 * *$ \\
\hline $\begin{array}{l}\text { Accumulated precipitation }>100 \mathrm{~mm} \\
(\mathrm{~mm})\end{array}$ & $0.35 * *$ & $0.40 * *$ & $0.50 * *$ \\
\hline Runoff $24 \mathrm{~h}(\mathrm{~mm})$ & $0.29 * *$ & $0.22 * *$ & $0.27^{* *}$ \\
\hline $\begin{array}{l}\text { Runoff } 24 \mathrm{~h}(\mathrm{~mm}) \text { for precipitation in } \\
24 \mathrm{~h} \text { with } \mathrm{T}>2 \text { years }\end{array}$ & $0.57 * *$ & $0.38 * *$ & $0.50 * *$ \\
\hline $\begin{array}{l}\text { Estimated runoff }(\mathrm{mm}) \text { for } \\
\text { accumulated precipitation }\end{array}$ & $0.41 * *$ & $0.27 * *$ & $0.35 * *$ \\
\hline $\begin{array}{l}\text { Estimated runoff }(\mathrm{mm}) \text { for } \\
\text { accumulated precipitation }>100 \mathrm{~mm}\end{array}$ & $0.60 * *$ & $0.44^{* *}$ & $0.55^{* *}$ \\
\hline
\end{tabular}

$*$ p-value $<0.1 ; * *$-value $<0.05$

Figure 8 shows the best correlation results and the histograms for each variable (precipitation and accumulated runoff) for all of the cases (extraordinary and catastrophic) when the accumulated total rainfall was greater than $100 \mathrm{~mm}$. As in catastrophic episodes, precipitation is more closely related to the density of damages (a correlation of 0.51 ), whereas runoff relates slightly better to total damage (0.60). This behaviour might be a consequence of the fact that the runoff already takes into account land use through the runoff coefficient. A larger population is associated with a larger impermeable surface and, thus, to a higher mean runoff value. 

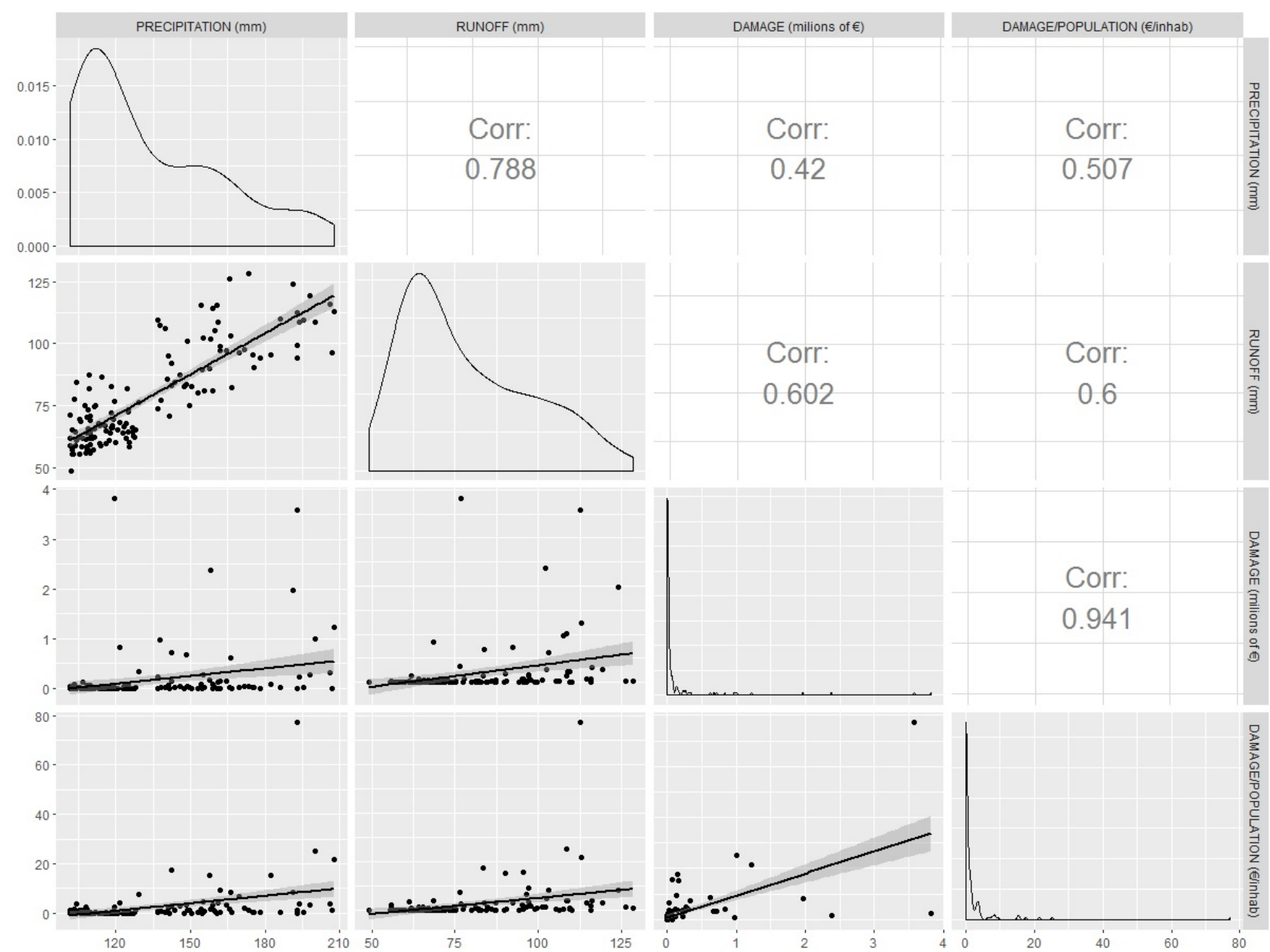

Fig. 8 Correlation results for extraordinary and catastrophic flood events where the total accumulated precipitation recorded was more than $100 \mathrm{~mm}$, over the 1996-2015 period (for which CCS data is available)

Finally, we analysed the distribution of precipitation over $24 \mathrm{~h}, 30$-min rainfall intensity, accumulated precipitation and damage according to the flood category (1: extraordinary, 2: catastrophic) (Figure 9 and Table 10). As could be expected, accumulated precipitation and damages are higher for catastrophic floods than for extraordinary ones. The extraordinary episodes have a mean maximum $24 \mathrm{~h}$ precipitation of 68 $\mathrm{mm}$, whereas catastrophic episodes have a mean maximum of $118 \mathrm{~mm}$. Furthermore, $75 \%$ of the former have a maximum $24 \mathrm{~h}$ value higher than $55 \mathrm{~mm}$. The maximum precipitation intensity values of the two categories are very high, at around $29 \mathrm{~mm}$ and $50 \mathrm{~mm}$ in 30 minutes for extraordinary and catastrophic episodes, respectively. These results confirm that the most common type of floods in this region, flash floods, come from intense and short precipitation events (Llasat et al. 2016).

The greatest differences in precipitation come from the total amount per episode, where the median for catastrophic floods was more than $175 \%$ larger than for extraordinary events. In fact, the latter have mean cumulative precipitation values equal to those of $24 \mathrm{~h}$ precipitation, indicating that the majority of episodes that produce extraordinary impacts have a duration of one day, as proposed in Llasat et al. (2016).

In terms of damages, catastrophic events produce median losses that exceed $€ 3$ million per episode, while in the case of extraordinary episodes these values are generally below $€ 1$ million. 


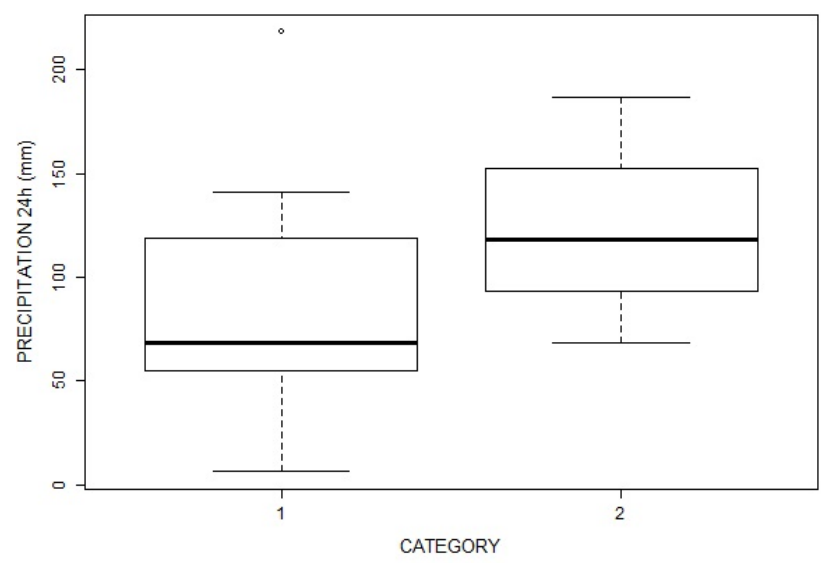

a

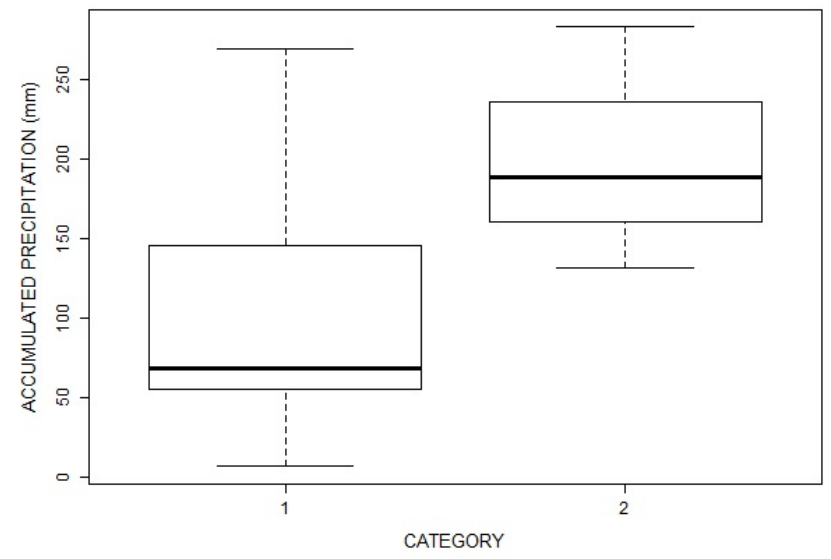

C

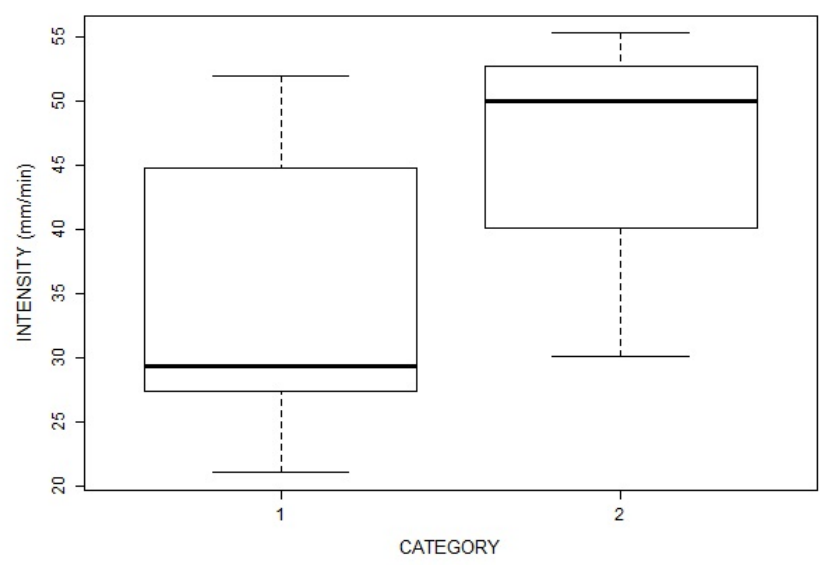

b

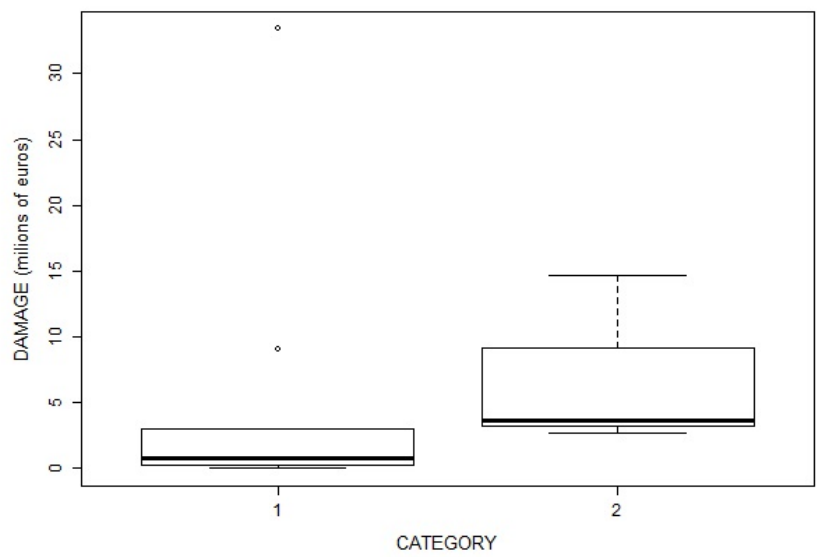

d

Fig. 9 Boxplots showing the distribution according to the flood category (1: extraordinary, 2: catastrophic): a) Precipitation in 24h; b) Precipitation in $30 \mathrm{~min}$; c) Accumulated precipitation; and d) Damage

Table 10 Quartiles $\left(\mathrm{Q} 1=25^{\text {th }}\right.$ percentile; $\mathrm{Q} 2=$ median; $\mathrm{Q} 3=75^{\text {th }}$ percentile) distribution for precipitation and damage variables according to flood category

\begin{tabular}{|l|r|r|r|r|r|r|}
\hline \multirow{2}{*}{} & \multicolumn{3}{|c|}{ EXTRAORDINARY } & \multicolumn{3}{c|}{ CATASTROPHIC } \\
\cline { 2 - 7 } & Q1 & Q2 & Q3 & Q1 & Q2 & Q3 \\
\hline Precipitation in 24h (mm) & 56 & 68 & 115 & 93 & 118 & 152 \\
\hline Intensity (mm/min) & 28 & 29 & 43 & 40 & 50 & 53 \\
\hline Accumulated precipitation $(\mathrm{mm})$ & 56 & 68 & 139 & 160 & 189 & 236 \\
\hline Damage (millions of $€$ ) & 0.21 & 0.71 & 2.67 & 3.14 & 3.63 & 9.12 \\
\hline
\end{tabular}




\section{Conclusions}

The Metropolitan Area of Barcelona (MAB) has been affected by 109 flood events between 1981 and 2015, which translates to an average of more than three episodes of flooding per year, some of them with catastrophic effects. As a result of these events, 11 people lost their lives between 1981 and 2015 and the compensation paid by the CCS exceeded $€ 86$ million between 1996 and 2015 . Consequently, there is no doubt that flooding is one of the most important natural hazards affecting Barcelona and its metropolitan area. The evolution of flood events (including urban floods and flash floods) shows a negative trend, although it is not significant. This result differs from the one obtained for different Mediterranean regions (Llasat et al. 2013) or Catalonia (Llasat et al. 2014a), where a positive and significant trend was found, mainly due to the increase in extraordinary events. In particular, in the case of the MAB, the analysis for the period 1981-2010 also shows a positive trend that is not significant (Llasat et al. 2016). This fact reflects the importance of period chosen when analysing trends, as well as other important points to be considered. The first is the improvement of prevention measures like constructing rainwater tanks, or the establishment of warning systems, which allows rainwater in the city to be better managed. This is the case in Barcelona, where a negative and significant trend was found, in agreement with the results for the analysis of longer periods (Barrera-Escoda et al. 2006). After the implementation of prevention measures, the seriousness of floods in this city has decreased, and nowadays the almost all events are ordinary floods. Similarly, the lack of a positive trend in precipitation extremes in this area could be another explanation (Turco and Llasat, 2011; Turco et al. 2015).

Other factor to be considered is related with land use changes. Despite the fact that $80 \%$ of the land devoted to agriculture in 1956 has been transformed in urban land with impermeable surfaces, the biggest change occurred between 1956 and 1993. After this date, there was a decrease of less than $50 \%$ in the agricultural area. When land surface changes are introduced in the calculation for runoff changes over a return period of 100 years, the changes shown in the city of Barcelona are negligible and there is only an increase of $5.5 \%$ for the entire MAB.

The same behaviour was observed for the increase in population. Despite the increase in population since 1950 (by more than 206\%), the last 35 years have only seen changes around $2 \%$ and, in the case of Barcelona, there has been a decrease as result of the high cost of living in the city. The correlation between accumulated precipitation and total damages is 0.23 . Given that we are referring to annual values and without considering the number of insurance policies, this correlation value is quite high. But higher correlations were found between precipitation, runoff and the density of damages (damages/population adjusted to each year). The correlation surpasses 0.5 when considering events that recorded more than 100 $\mathrm{mm}$ in 24 hours, or that have a return period of more than 2 years. Particularly, the correlation between estimated average runoff and total damages in the event, at municipal scale, is 0.60 .

This study suggested a classification of flood events in basis of different impact indicators. In a preliminary analysis of the 1981-2015 period, the MAB has driven to the possibility of suggesting some thresholds. In this case, an extraordinary flood event would be characterised by an average daily precipitation of around $68 \mathrm{~mm}$, a maximum intensity of $30 \mathrm{~mm}$ in 30 minutes, and $€ 1$ million in damages respectively (insured damages). These values would be for a catastrophic flood of $118 \mathrm{~mm}, 50 \mathrm{~mm}$ and $€ 3$ million, respectively.

Despite this apparent success, and given that torrential rainfall may increase in the future and the MAB is one of the regions of the world with the highest number of tourists, preventive measures should still be improved, including making sure the population is more aware of the risk. This improvement of the risk awareness should be done at regional scale (informative leaflets, schools...) including local interventions like exhibitions, conferences and the development of citizen science projects and tools. Although the rainwater tanks have been useful in the city of Barcelona, new infrastructures for flood defence should be avoided, with the focus on more sustainable solutions instead. For example, allow the Llobregat and Besòs rivers to have their natural and historical space; transform flood plains into permanently open and green spaces beside and inside the cities (a good solution in areas not so much urbanised); improve new ways of channelling rainwater to these spaces; use river spaces as natural reservoirs, allowing floods to reach the coastline wherever possible, so they can fulfil their natural function in regenerating beaches and coastal 
ecosystems. In high urbanized areas it would be important to improve drainage systems taking into account the new proposals for Sustainable Urban Drainage Systems (SUDS). Between the no structural measures, the improvement of the early warning systems from a hydrometeorological point of view (rainfall and runoff) is a key issue. However, besides the sustainability criteria we cannot forget the limits imposed by the propagation of the uncertainty associated to the rainfall field in the hydrometeorological chain, the required societal consensus, the assumable costs, and the own technology (Llasat and Siccardi, 2010).

The latest IPCC report (2014) points to an increased risk of flooding, but above all, of associated socioeconomic impacts. According to the Hyogo and Sendai frameworks, the most recent agreements regarding natural hazards and disasters (UNISDR, 2007, 2015a), and the 2015-2030 Sustainable Development Goals, prevention and resilience to floods must have a strong social and sustainable component. This can only be achieved through better empowerment and co-responsibility, not only from the population, but also from the private sector and local governments.

\section{Acknowledgements}

This work has been supported by the Spanish Project HOPE (CGL2014-52571-R) of the Ministry of Economy, Industry and Competitiveness, and the Metropolitan Area of Barcelona Project (no. 308321) (Flood evolution in the Metropolitan Area of Barcelona from a holistic perspective: past, present and future). It was developed in the framework of the HyMeX Programme (HYdrological cycle in the Mediterranean EXperiment). We would like to thank AEMET, SMC and ACA for the meteorological and hydrological information provided for this study. Thanks also to BCASA for the detailed information about the system used to prevent and manage floods. M. Turco was supported by the Spanish Juan de la Cierva Programme (grant code: IJCl-2015-26953). We would also like to acknowledge Hannah Bestow for the correction of the English language of this paper.

\section{References}

Alfieri L, Feyen L, Di Baldassarre G (2016) Increasing flood risk under climate change: a pan-European assessment of the benefits of four adaptation strategies. Climatic Change, 136(3-4): 507-521

Amaro J, Gayà M, Aran M, Llasat MC (2010) Preliminary results of the Social Impact Research Group of MEDEX: the request database (2000-2002) of two Meteorological Services. Nat Hazards Earth Syst Sci 10(12): 26432652. doi:10.5194/nhess-10-2643-2010

Barbería L, Amaro J, Aran M, Llasat MC (2014) The role of different factors related to social impact of heavy rain events: considerations about the intensity thresholds in densely populated areas. Natural Hazards and Earth System Science, 14(7), 1843-1852. http://doi.org/10.5194/nhess-14-1843-2014

Barnolas M, Llasat MC (2007) Metodología para el estudio de inundaciones históricas en España e implementación de un SIG en las cuencas del Ter, Segre y Llobregat. Centro de Estudios Hidrográficos (CEDEX). España

Barredo JI, Saurí D, Llasat MC (2012) Assessing trends in insured losses from floods in Spain 1971-2008. Nat Hazards Earth Syst Sci 12(5): 1723-1729

Barrera-Escoda A, Llasat MC (2015) Evolving flood patterns in a Mediterranean region (1301-2012) and climatic factors - the case of Catalonia. Hydrol Earth Syst Sci 19: 465-483. doi: 10.5194/hess-19-465-2015

Barrera-Escoda A, Llasat MC, Barriendos M (2006) Estimation of the extreme flash flood evolution in Barcelona county from 1351 to 2005. Nat Hazards Earth Syst Sci 6:505-518

Barriendos M, Coeur D, Lang M, Llasat MC, Naulet R, Lemaitre F, Barrera A (2003) Stationarity analysis of historical flood series in france and spain (14th-20th centuries). Natural Hazards and Earth System Sciences, 3, 583-592

Benoit G, Comeau A (2005) A Sustainable Future for the Mediterranean: The Blue Plan's Environment and Development Outlook. Earthscan 
Blöschl G, Viglione A, Montanari A (2013) Emerging Approaches to Hydrological Risk Management in a Changing World. In: Climate Vulnerability: Understanding and Addressing Threats to Essential Resources. Elsevier Inc, Academic Press, pp 3-10

Bodoque JM, Amérigo M, Díez-Herrero A, García JA, Cortés B, Ballesteros-Cánovas JA, Olcina J (2016) Improvement of resilience of urban areas by integrating social perception in flash-flood risk management. Journal of Hydrology 541:665-676

Casas-Castillo C, Cunillera J, Xènia D, Herrero M, Ninyerola M, Xavier P, Redaño A, Rius A, Rodriguez R (2005) Mapes de precipitació màxima diària esperada a catalunya per a diferents períodes de retorn. Servei Meteorològic de Catalunya, Departament de Medi Ambient i Habitatge: Generalitat de Catalunya, ISBN: 84393-6870-4

Ceola S, Laio F, Montanari A (2014) Satellite nighttime lights reveal increasing human exposure to floods worldwide. Geophysical Research Letters 41(20):7184-7190

Chow VT, Maidment DR, Mays LW (1988) Applied hydrology. Mc Graw Hill

Del Moral A, Llasat MC, Rigo T (2016) Identification of anomalous motion of thunderstorms using daily rainfall fields, Atmos. Res., 185, 92-100, doi:10.1016/j.atmosres.2016.11.001

Drobinski P, Ducrocq V, Alpert P, Anagnostou E, Béranger K, Borga M, ... Wernli H (2014) HyMeX: A 10-year multidisciplinary program on the Mediterranean water cycle. Bull Amer Meteor Soc 95(7):1063-1082 doi: 10.1175/BAMS-D-12-00242.1

Eurostat (2016) Eurostat regional yearbook. http://ec.europa.eu/eurostat/statisticsexplained/index.php/Regional_yearbook_introduction. Accessed 3 July 2017

Faccini F, Luino F, Sacchini A, Turconi L (2015) Flash flood events and urban development in Genoa (Italy): lost in translation. In Engineering Geology for Society and Territory-Volume 5. Springer International Publishing, pp 797-801

García LE, Matthews JH, Rodriguez DJ, Wijnen M, DiFrancesco KN, Ray P (2014) Beyond Downscaling: A Bottom-Up Approach to Climate Adaptation for Water Resources Management. AGWA Report 01. Washington, DC: World Bank Group

Gascón E, Laviola S, Merino A, Miglietta MM (2016) Analysis of a localized flash-flood event over the central Mediterranean. Atmospheric Research 182:256-268

Hall J, Arheimer B, Borga M, Brázdil R, Claps P, Kiss A., ... Blöschl G (2014). Understanding flood regime changes in Europe: a state-of-the-art assessment. Hydrology and Earth System Sciences 18:2735-2772 doi: 10.5194/hess-18-2735-2014

Hirabayashi Y, Mahendran R, Koirala S, Konoshima L, Yamazaki D, Watanabe S, ... Kanae S (2013) Global flood risk under climate change. Nature Climate Change 3(9): 816-821

Institut d'Estadística de Catalunya (IDESCAT, Statistical Institute of Catalonia) (2016) Anuari estadístic de Catalunya (Statistical Yearbook of Catalonia). http://www.idescat.cat/. Accessed 28 February 2017

Instituto Nacional de Estadística (INE). http://www.ine.es/. Accessed 28 February 2017

IPCC (2012) Managing the risks of extreme events and disasters to advance climate change adaption (SREX). Intergovernmental Panel on Climate Change. Cambridge University Press, Cambridge

IPCC (2014) Climate Change 2014: Impacts, Adaptation, and Vulnerability. IPCC Working Group II Contribution to the Fifth Assessment Report of the Intergovernmental panel on climate change. http://www.ipcc.ch/report/ar5/wg2/.

Karagiorgos K, Thaler T, Hübl J, Maris F, Fuchs S (2016) Multi-vulnerability analysis for flash flood risk management. Natural Hazards 82(1): 63-87

Kendall MG (1975) Rank Correlation Methods. Oxford Univ. Press, New York

Llasat MC, Siccardi F (2010) A reflection about the social and technological aspects in flood risk management the case of the Italian Civil Protection. Nat. Hazards Earth Syst. Sci., 10, 109-119 
Llasat MC, Barriendos M, Barrera A, Rigo T (2005) Floods in Catalonia (NE Spain) since the 14th century. Climatological and meteorological aspects from historical documentary sources and old instrumental records. Journal of Hydrology. Applications of palaeoflood hydrology and historical data in flood risk analysis 313:32-47

Llasat MC, Llasat-Botija M, López L (2009) A press database on natural risks and its application in the study of floods in Northeastern Spain. Nat Hazards Earth Syst Sci 9:2049-2061

Llasat MC, Llasat-Botija M, Petrucci O, Pasqua AA, Rosselló J, Vinet F, Boissier L (2013) Towards a database on societal impact of Mediterranean floods in the framework of the HYMEX project. Nat Hazards Earth Syst Sci 13:1-14

Llasat MC, Marcos R, Llasat-Botija M, Gilabert J, Turco M, Quintana-Seguí P (2014a) Flash flood evolution in North-Western Mediterranean. Atmospheric Research 149:230-243

Llasat MC, Turco M, Quintana-Seguí P, Llasat-Botija M (2014b) The snow storm of 8 March 2010 in Catalonia (Spain): a paradigmatic wet-snow event with a high societal impact. Nat Hazards Earth Syst Sci 14:427-441. doi:10.5194/nhess-14-427-2014

Llasat MC, Marcos R, Turco M, Gilabert J, Llasat-Botija, M (2016) Trends in flash flood events versus convective precipitation in the Mediterranean region: The case of Catalonia. Journal of Hydrology 541: 24-37

Mann HB (1945) Nonparametric tests against trend. Econometrica 13:245-259

Martín Vide J, (coord.) et al (2016) Tercer Informe sobre el canvi climàtic a Catalunya (Third Report in Climate Change in Catalonia). Generalitat de Catalunya-Institut d'Estudis Catalans. ISBN 9788499653174 (IEC). ISBN 9788439394488 (Generalitat de Catalunya) Barcelona: 611 pp.

Mediero L, Jiménez-Álvarez A, Garrote L (2010) Design flood hydrographs from the relationship between flood peak and volume. Hydrology and Earth System Sciences 14(12):2495

Merz B, Kreibich H, Schwarze R, Thieken A (2010) Review article "assessment of economic flood damage." Nat Hazards Earth Syst Sci 10:1697-1724. doi: 10.5194/nhess-10-1697-2010

Nakamura I, Llasat MC (2017) Flood Risk Management and Information - A Comparative Study between Japan and Spain on Flood Risk and Warning - Nat. Hazards. 87: 919. doi:10.1007/s11069-017-2802-x

Schröter K, Kunz M, Elmer F, Mühr B, Merz B (2015) What Made the June 2013 Flood in Germany an Exceptional Event? A Hydro-Meteorological Evaluation. Hydrology and Earth System Sciences 19(1): 309-27

Terti G, Ruin I, Anquetin S, Gourley JJ (2015) Dynamic vulnerability factors for impact-based flash flood prediction. Natural Hazards 79(3):1481-1497

Thieken AH, Bessel T, Kienzler S, Kreibich H, Müller M, Pisi S, Schröter K (2016) The Flood of June 2013 in Germany: How Much Do We Know about Its Impacts? Natural Hazards and Earth System Sciences Discussions (January): 1-57

Turco M, Llasat MC (2011) Trends in indices of daily precipitation extremes in Catalonia (NE Spain). 1951-2003, Nat Hazards Earth Syst Sci 11:3213-3226

Turco M, Marcos R, Quintana-Seguí P, Llasat MC (2014) Testing instrumental and downscaled reanalysis time series for temperature trends in NE of Spain in the last century. Reg Environ Change 14:1811. doi:10.1007/s10113-012-0363-9

Turco M, Palazzi E, von Hardenberg J, Provenzale A (2015) Observed climate change hotspots. Geophys Res Lett 42: 3521-3528. doi: 10.1002/2015GL063891

Turco M, Llasat MC, Herrera S, Gutiérrez JM (2017) Bias correction and downscaling of future RCM precipitation projections using a MOS-Analog technique. J Geophys Res Atmos, 122. doi:10.1002/2016JD025724

UNISDR (United Nations International Strategy for Disaster Reduction) (2007) Hyogo Framework for Action 2005-2015. https://www.unisdr.org/we/coordinate/hfa. Accessed 28 February 2017

UNISDR (United Nations International Strategy for Disaster Reduction) (2015a) Sendai framework for disaster risk reduction 2015-2030. http://www.unisdr.org/files/43291_sendaiframeworkfordrren.pdf. Accessed 28 February 2017 
UNISDR (United Nations International Strategy for Disaster Reduction) (2015b) Making Cities Resilient: My City is Getting Ready. http://www.unisdr.org/campaign/resilientcities. Accessed 28 February 2017

Wilby RL, Dessai S (2010) Robust adaptation to climate change. Weather 65(7):180-185

WMO (World Meteorological Organization) (2009) Guidelines on analysis of extremes in a changing climate in support of informed decisions for adaptation. Tech. Rep. WCDMP 72, Geneva, Switzerland 